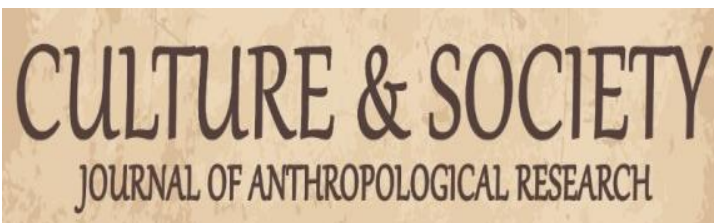

Culture \& Society: Journal of Anthropological Research

VOL. 1 NO. 4 JUNI 2020

http://culture.ppi.unp.ac.id

Email: culture@ppj.unp.ac.id

ISSN: 2686-343X (E-ISSN) 2686-3421 (P-ISSN)

DOI: https://doi.org/10.24036/csjar.v1i4.39

\title{
Modal Sosial Orang Rimba Bagi Pendidikan Formal Anak
}

\author{
Murni Purwasih ${ }^{1}$, Erda Fitriani ${ }^{2}$ \\ ${ }^{1,2}$ Universitas Negeri Padang; Padang, Indonesia \\ Email : murnip936@gmail.com, fitriani_cim@fis.unp.ac.id
}

\begin{abstract}
Abstrak
Penelitian ini bertujuan untuk menjelaskan modal sosial Orang Rimba pada pendidikan formal tepatnya pada anak-anak Orang Rimba yang sekolah di SDN 89/VII Desa Pulau Lintang Kecamatan BathinVIII Kabupaten Sarolangun Provinsi Jambi. Teori yang digunakan untuk menganalisis penelitian ini ialah teori modal sosial yang dikemukakan oleh Putnam. Menurut Putnam modal sosial adalah jaringanjaringan, nilai-nilai, dan kepercayaan. Metode yang dilakukan dalam penelitian ini ialah pendekatan kualitatif dengan tipe studi kasus serta teknik pemilihan informan yaitu snowball sampling. Pengumpulan data dilakukan dengan cara observasi, wawancara mendalam, dokumentasi dengan teknik analisis data dari Miles dan Huberman. Hasil penelitian ini menunjukkan modal sosial yang dimiliki Orang Rimba untuk meyekolahkan anak-anak pada pendidikan formal yaitu (1). Jaringan, dimana dengan adanya hubungan sosial yang sudah dijalin masyarakat Orang Rimba dengan pemerintah dan guru nonformal maka membuka wawasan pengetahuan mereka untuk menyekolahkan anak mereka ke pendidikan formal; (2). Nilai dan Norma, nilai yang dianut Orang Rimba yaitu nilai kesopanan, nilai saling menghargai dan nilai saling tolong menolong; (3). Kepercayaan, kepercayaan Orang Rimba dengan hubungan sosial yang sudah terjalin antara Orang Rimba dengan pemerintah, guru pendidikan nonformal dan pendeta; Jenis modal sosial yang ada pada masyarakat Orang Rimba adalah jenis modal sosial bonding dan bridging.
\end{abstract}

Kata kunci: Modal sosial, Orang Rimba, Pendidikan Formal, Anak

\section{Abstract}

This study aims to explain the social capital of the Jungle People in formal education precisely in the Orang Rimba children who study at SDN 89 / VII Pulau Lintang Village, BathinVIII District, Sarolangun Regency, Jambi Province. The theory used to analyze this research is the theory of social capital put forward by Putnam. According to Putnam social capital is networks, values, and trust. The method used in this research is a qualitative approach with the type of case studies and informant selection techniques namely snowball sampling. Data collection was carried out by means of observation, in-depth interviews, documentation with data analysis techniques from Miles and Huberman. The results of this study indicate the social capital owned by the Orang Rimba to educate children in formal education, namely (1). Network, where the existence of social relations that have been forged by the Orang Rimba community with the government and non-formal teachers opens their knowledge horizons to send their children to formal education; (2). Values and Norms, values adopted by the Orang Rimba namely the value of politeness, the value of mutual respect and the value of mutual help; (3). The trust, the confidence of the Jungle People with the existing social relations between the Jungle People and the government, non-formal education teachers and priests; The type of social capital that exists in the Orang Rimba community is the type of social capital bonding and bridging.

Keywords: Social Capital, Jungle People, Formal Education, Children

\begin{tabular}{l|l|l} 
Received: April 26, 2020 & Revised: May 21, 2020 & Published: May 22, 2020
\end{tabular}

Culture \& Society: Journal of Anthropological Research Vol. 1, No. 4, Th. 2020 


\section{Pendahuluan}

Pendidikan memiliki peranan penting dalam kemajuan seorang individu, kelompok masyarakat, sukubangsa bahkan kehidupan suatu bangsa. Menurut Hasbullah dalam ((Rahmi Fadilatur, Junaidi, 2019) Pendidikan merupakan usaha yang dilakukan oleh seseorang atau kelompok agar mereka menjadi dewasa dan dapat mencapai tingkat hidup yang semakin tinggi untuk menguji mental. Seluruh warga Negara Indonesia memiliki hak yang sama untuk mendapatkan pendidikan begitu pula halnya dengan Orang Rimba, mereka juga berhak untuk mendapatkan pendidikan dan pengetahuan agar bisa hidup dengan layak karena jika individu atau kelompok sudah tidak melakukan pendidikan, tak bisa disangka apa yang akan terjadi dalam sistem peradaban manusia. Dengan demikian, pemerintah maupun masyarakat mengupayakan pendidikan dengan standar pendidikan yang baik bagi pemberdayaan manusia. Namun, Suku Anak Dalam atau Orang Rimba yang pada dasarnya lebih suka berburu dan melangun, sehingga mereka kurang bisa menerima jika ada perubahan serta adanya sesuatu hal yang baru dari kebiasaan yang mereka lakukan, dan kurang mau menerima kemajuan dan perkembangan. Orang rimba akan lebih sulit menerima hal baru, walaupun sudah diberikan penjelasan tentang hal baru seperti pendidikan. Mereka tetap lebih memilih melangun dari pada mereka harus duduk di kelas untuk belajar di sekolah dan mendengarkan, apa lagi harus memperhatikan pelajaran yang disampaikan oleh orang yang mengajar (Hidayat et al, 2013). Sebelumnya Orang Rimba tidak pernah mendapatkan pendidikan karena mereka kurang terbuka dengan masyarakat di luar sukubangsanya dan mereka juga kurang terbuka dengan hal-hal baru. Orang Rimba akan merasa malu saat bertemu dengan masyarakat di luar sukubangsanya, hal tersebut karena adanya anggapan walaupun Orang Rimba bisa membaca dan menulis akan tetap dibodohi oleh masyarakat di luar sukubangsanya, dan tidak semua orang bisa membuat Orang Rimba terbuka dengan berbagai hal yang baru. Kebiasaan yang terdapat pada Orang Rimba memiliki tujuan yang menentang pendidikan karena bagi Orang Rimba hal yang dapat merubah kebiasaan mereka ialah pendidikan (Lestari, 2015).

Orang Rimba memiliki pemikiran yang negatif jika sekolah di pendidikan formal. Hal tersebut mereka dapatkan sesuai dengan ajaran orang tua mereka, tumenggung (kepala suku), dan nenek moyang mereka dahulu. Menurut mereka, pendidikan yang akan didapatkan di sekolah bukanlah suatu kegiatan yang harus mereka lakukan karena jika mereka belajar di sekolah, mereka akan kehilangan waktu untuk berhutan, sehingga ancaman yang timbul ialah jika mereka tidak bisa memenuhi kebutuhan hidup mereka dari berhutan maka mereka akan meninggal dunia (Hidayat et al, 2013).

Hal tersebut membuat Orang Rimba memiliki perspektif negatif terhadap pendidikan formal. Sehingga tidak mudah untuk membuat Orang Rimba mau menerima pendidikan formal, dan pendidikan formal merupakan hal yang baru bagi Orang Rimba. Dengan belajar di pendidikan formal diharapkan siswa mampu mengambil keputusan serta mampu mengembangkan potensi diri dalam upaya meningkatkan kualitas diri, keluarga, kelompok, agama, bangsa dan negara dengan cepat. Semua ini merupakan unsur pokok dalam proses pembentukan masyarakat yang sejahtera, bertahan, adil, makmur, dan penuh kedamaian (Juanda, 2010).

Pendidikan formal merupakan kegiatan terstruktur, berjenjang, sistematis dan bertingkat sejak Sekolah Dasar sampai ke Perguruan Tinggi ataupun yang setara dengannya termasuk dalam kegiatan belajar yang berorientasi akademis dan umum, program latihan profesional yang dilakukan secara terus menerus (Sudjana, 2004). Hal tersebut pastinya sangat bertentangan dengan kebiasaan-kebiasaan masyarakat Orang Rimba karena mereka bertempat tinggal di dalam hutan dan mereka hanya memanfaatkan sumber daya alam yang ada di dalam hutan agar bisa memenuhi kebutuhan hidupnya setiap hari sehingga mereka hanya menghabiskan hidupnya sehari-hari di dalam hutan saja.

Namun pada saat ini anak-anak Orang Rimba tepatnya di desa Pulau Lintang Kecamatan Bathin VIII Kabupaten Sarolangun sudah tidak membatasi diri mereka dengan masyarakat di luar

Culture \& Society: Journal of Anthropological Research Vol. 1, No. 4, Th. 2020 
sukubangsanya lagi, hal ini terlihat dari jumlah anak-anak Orang Rimba yang sudah sekolah di sekolah formal tepatnya di SDN 89/VII Desa Pulau Lintang. Anak-anak Orang Rimba ini satu sekolah dengan anak-anak desa lainnya dan tidak ada kelas khusus bagi anak-anak Orang Rimba di sekolah tersebut. Mereka bergabung dengan anak-anak desa sesuai dengan tingkat kelasnya masing-masing. Bahkan sebelumnya tidak ada orang tua mereka yang pernah sekolah. Pada saat ini hanya satu orang yang sudah melanjutkan pendidikannya ke jenjang SMP, selebihnya anakanak Orang Rimba masih duduk di tingkat Sekolah Dasar (SD). Dari penjelasan tersebut dapat dilihat bahwa anak-anak Orang Rimba di desa Pulau Lintang ini sudah sekolah di pendidikan formal dan mau bergabung dengan anak-anak desa di luar sukubangsanya. Hal tersebut membuat penulis ingin mencari tahu modal sosial Orang Rimba pada pendidikan formal.

Menurut Putnam (1995) dalam (Febriani, Darusman, Ridho Nurrochmat, \& Wijayanto, 2012) mengatakan modal sosial adalah jaringan kerja, norma dan kepercayaan sosial yang memfasilitasi kerjasama dan koordinasi untuk mendapatkan keuntungan bersama. Modal sosial juga bisa berperan sebagai pengikat semua orang dalam kelompok masyarakat untuk hidup bersama dan tentram. Sehingga berkembangnya modal sosial di dalam masyarakat dapat membuat masyarakat yang mandiri dan bisa berperan menciptakan suatu situasi masyarakat yang toleran, partisipasif, dan merangsang tumbuhnya empati dan simpati terhadap kelompok masyarakat atau di luar kelompoknya, saling membantu, saling tolong menolong, gotong royong, serta memiliki rasa senasip seperjuangan diantara masyarakat yang akan menghasilkan kehidupan yang tentram dan damai (Inayah, 2012)

Modal sosial yang di maksud dalam penelitian ini adalah sesuatu yang muncul akibat adanya interaksi antar individu dalam komunitas yang kemudian menjadi tumpuan untuk tetap bertahan hidup. Kekuatan tersebut tercipta karena adanya jalinan hubungan di dalamnya. Seperti sikap saling memperhatikan, menerima dan memberi, saling percaya dengan di perkuat oleh nilai dan norma yang mendukungnya. Serta dipahami sebagai kepercayaan yang dimiliki oleh masyarakat kepada individu atau kelompok yang ada di dalamnya. Lalu mereka membuat kesepakatan bersama sebagai suatu nilai dalam kelompoknya. Kemudian aspirasi masyarakat mulai tersampaikan, komunitas dan kelembagaan teradaptasi sebagai suatu modal pengembangan kelompok dan pemberdayaan masyarakat (Kamarni, 2012).

Penelitian yang relevan dengan penelitian ini adalah penelitian yang dilakukan oleh Eci Ritami yang berjudul peran modal sosial dalam memperkuat strategi bertahan hidup penambang batu (2012) hasil penelitiannya mengatakan modal sosial yang terdapat dalam kehidupan penambang batu mencakup tiga unsur yaitu jaringan sosial, kepercayaan dan norma. Pertama, jaringan yang berkembang pada kelompok penambang batu ialah membentuk hubungan kerjasama antara penambang batu, konsumen dan pemilik lahan.

Jaringan tersebut sangat kuat karena rasa persaudaraan dan pertemanan yang sudah tejalin. Kedua, kepercayaan pada penambang batu dapat terlihat dari kepercayaan diri dari hubungan sosial yang terjalin antara penambang batu dengan penambang batu lainnya, penambang batu dengan orang yang mempunyai lahan, dan antara penambang batu dengan konsumen dan juga dengan tetangga atau warga sekitar. Ketiga, norma dalam kehidupan penambang batu dapat dilihat kesepakatan yang telah di buat antara sesama penambang batu dan pemilik lahan untuk membayar sewa lahan. Norma yang ada dalam kehidupan penambang batu juga berupa sikap saling tolong menolong, sikap saling membantu dan saling berbagi (Ristami, 2016).

Penelitian yang dilakukan oleh Gina Nefsia Shabrina yang berjudul peranan modal sosial dalam meningkatkan efektivitas program Corporate Responsibility dan taraf hidup mayarakat, hasil penelitiannya mengatakan Modal Sosial masyarakat desa bantar karet dilihat dari terpeliharanya kepercayaan antar masyarakat dengan aparatur desa yang cenderung kuat, hubungan sosial yang cenderung lemah dan jaringan yang terbentuk dalam masyarakat yang juga cenderung kuat sehingga masyarakat tergolong mudah dalam mendapatkan pekerjaan formal, pendidikan maupun fasilitas kesehatan (Shabrina, 2015).

Culture \& Society: Journal of Anthropological Research Vol. 1, No. 4, Th. 2020 


\section{Metode Penelitian}

Penelitian mengenai modal sosial Orang Rimba bagi pendidikan formal ini dilakukan di Desa Pulau Lintang Kecamatan Bathin VIII Kabupaten Sarolangun Provinsi Jambi selama 2 bulan mulai dari tanggal 14 November 2019 sampai tanggal 15 Januari 2020. Alasan penulis melakukan penelitian di Desa Pulau Lintang Kecamatan Bathin VIII ini ialah karena anak-anak Orang Rimba di desa ini sudah sekolah di pendidikan formal tepatnya di SDN 89/VII Desa Pulau Lintang. Dalam penelitian ini peneliti menggunakan penelitiaan kualitatif yaitu dilakukan dengan cara observation participation untuk membuat deskripsi, gambaran, lukisan atau makna secara sistematik, mendalam, faktual dan akurat mengenai fakta-fakta (Mulyadi, 2013). Pada penelitian kualitatif yang penulis lakukan ini, peneliti menggunakan latar belakang ilmiah dengan maksud menafsikan fenomena yang terjadi. Dalam penelitian ini penulis berupaya untuk memahami peristiwa dan gejala yang terjadi di lapangan yang berkaitan dengan modal sosial Orang Rimba bagi pendidikan formal. Penelitian ini menggunakan jenis penelitian studi kasus dimana penelitian ini memusatkan diri secara terus menerus pada satu objek tertentu yang mempelajarinya sebagai suatu keadaan (Nawawi, 2012). Pemilihan informan pada penelitian ini dilakukan secara snowball sampling karena pengambilan data awalnya berjumlah kecil, kemudian baru di kembangkan dengan jumlah sampel yang banyak. informan dipilih berdasarkan pengetahuannya dan mampu memberikan data sesuai dengan tujuan penelitian. Oleh karena ini yang menjadi subjek penelitian ialah keluarga Orang Rimba yang menyekolahkan anak-anaknya di sekolah formal, anak-anak Orang Rimba yang sekolah di sekolah formal, guru yang mengajar dan tumenggung (kepala suku) Orang Rimba. Jumlah informan dalam penelitian ini yaitu 17 orang.

Teknik observasi yang digunakan dalam penelitian ini bertujuan untuk mendapatkan data dengan cara mengamati langsung dan melakukan pencatatan secara sistematik terhadap apa yang diteliti. Selanjutnya melakukan wawancara mendalam yaitu menggali informasi secara mendalam, terbuka, dan bebas. Metode wawancara mendalam ini dilakukan dengan menggunakan daftar pertanyaan yang telah dipersiapkan sebelumnya serta menggunakan bahasa yang bisa dipahami oleh infoman agar informan mengerti dan paham dengan pertanyaan yang diberikan oleh peneliti. Wawancara dilakukan secara terbuka yaitu informan dan peneliti samasama mengetahui tujuan dari wawancara yang dilakukan oleh peneliti. Selanjutnya teknik dokumentasi, dimana dokumen yang diterima oleh peneliti berupa data-data yang berhubungan dengan penelitian yang sudah peneliti lakukan, serta dokumentasi yang peneliti dapatkan saat melakukan penelitian di lapangan secara langsung. Agar data yang peneliti dapatkan saat penelitiaan akurat, peneliti melakukan triangulasi data dengan menguji apakah proses dan metode yang digunakan peneliti selama di lapangan sudah berjalan dengan baik atau belum. Triangulasi merupakan cara untuk memeriksa kebenaran data dengan memanfaatkan hal lain di luar data itu sendiri agar bisa menjadi pembanding dari data itu sendiri (Bachri, 2010). Triangulasi data merupakan cara peneliti untuk melihat atau memeriksa keabsahan data dengan memanfaatkan sesuatu yang berada di luar data tersebut. Data yang sama kemudian dikelompokkan dengan tujuan untuk mengecek atau membandingkan dengan data yang telah peneliti peroleh (Burhan, 2011). Teknik analisis yang peneliti gunakan ialah teknik analisis data dari Miles dan Huberman.

\section{Hasil dan Pembahasan}

\section{Modal Sosial Orang Rimba Bagi Pendidikan Formal Anak}

Orang Rimba yang tinggal di Desa Pulau Lintang ini sudah tinggal menetap di rumah permanen yang dibuat oleh pemerintah, mereka tidak lagi tinggal berpindah-pindah. Walaupun tempat tinggal mereka yang sekarang masih berada di tengah hutan dan tidak terlalu dekat dengan jalan raya dan pemukiman warga lainnya. Orang Rimba di Desa Pulau Lintang ini menyekolahkan anak-anaknya di sekolah formal tepatnya di SD N 89/VII Desa Pulau Lintang. Mereka belajar di sekolah yang sama dengan anak-anak desa di luar suku bangsanya. Sebelum

Culture \& Society: Journal of Anthropological Research Vol. 1, No. 4, Th. 2020 
adanya anak-anak yang sekolah di sekolah formal, Orang Rimba sudah memiliki pendidikan nonformal yang dikelola oleh organisasi NGO yaitu KKI WARSI. Sekolah nonformal dilakukan di pemukiman tempat mereka tinggal, guru-guru yang mengajar datang ke pemukiman Orang Rimba untuk mengajar anak-anaknya menulis, berhitung dan membaca. Hingga saat ini anakanak Orang Rimba tersebut tetap mendapatkan pendidikan nonformal walaupun mereka sudah sekolah di sekolah formal, sekolah nonformal tersebut di lakukan setiap hari Jum'at, sabtu dan minggu mulai dari jam dua siang sampai jam 5 sore.

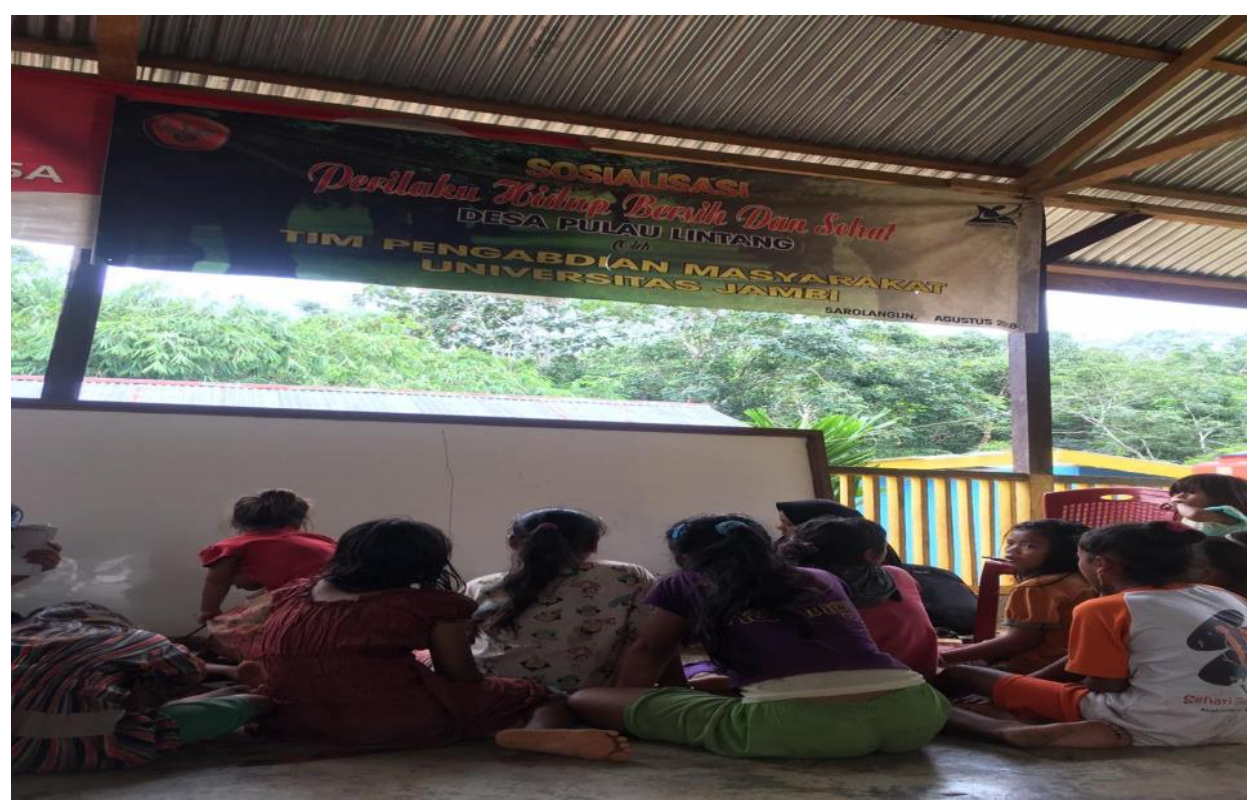

Gambar 1. Belajar tambahan yang di lakukan di pemukiman Orang Rimba

Di sekolah formal khususnya di SDN 89/VII Desa Pulau Lintang ini anak-anak Orang Rimba tidak memiliki kelas khusus, mereka belajar di satu kelas yang sama dengan anak-anak desa sesuai dengan tingkatan kelasnya masing-masing. Dari hasil penelitian yang peneliti lakukan, anak-anak Orang Rimba sekolah dengan menggunakan seragam lengkap seperti anak-anak desa lainnya, guru di sekolah tersebut juga mengungkapkan kalau tidak ada kesulitan sama sekali saat mengajar anak-anak Orang Rimba tersebut. Bahkan menurut data yang peneliti peroleh beberapa anak-anak Orang Rimba memiliki prestasi yang baik di sekolah, yaitu mendapatkan peringkat kelas bahkan ada yang mengikuti lomba lari dan solo song tingkat kecamatan. Hal tersebut membuktikan bahwa anak-anak Orang Rimba mampu bersaing dengan lingkungannya walaupun di luar kelompok sukubangsanya. Berikut data prestasi yang di peroleh anak-anak Orang Rimba di SDN 89/VII Desa Pulau Lintang:

Tabel 1. Prestasi anak-anak Orang Rimba di SDN 89/VII Desa Pulau Lintang

\begin{tabular}{|c|c|}
\hline Nama Siswa & Prestasi \\
\hline Nartani (kelas 6) & $\begin{array}{ll}- & \text { Peringkat } 1 \text { dikelas } 1 \\
\text { - } & \text { Peringkat } 2 \text { di kelas } 2 \text { dan } 3 \\
\text { - } & \text { Peringkat } 1 \text { di kelas 4-6 } \\
\end{array}$ \\
\hline Andi (kelas 6) & - $\quad$ Juara satu solo song \\
\hline Nodi (kelas 6) & $\begin{array}{ll}\text { - } & \text { Peringkat } 2 \text { di kelas } 1 \\
\text { - } & \text { Peringkat } 3 \text { di kelas 2-6 } \\
\text { - } & \text { Mengikuti lomba O2SN cabang atletik }\end{array}$ \\
\hline
\end{tabular}

Sumber: Arsip sekolah SDN 89/VII Desa Pulau Lintang

Culture \& Society: Journal of Anthropological Research Vol. 1, No. 4, Th. 2020 


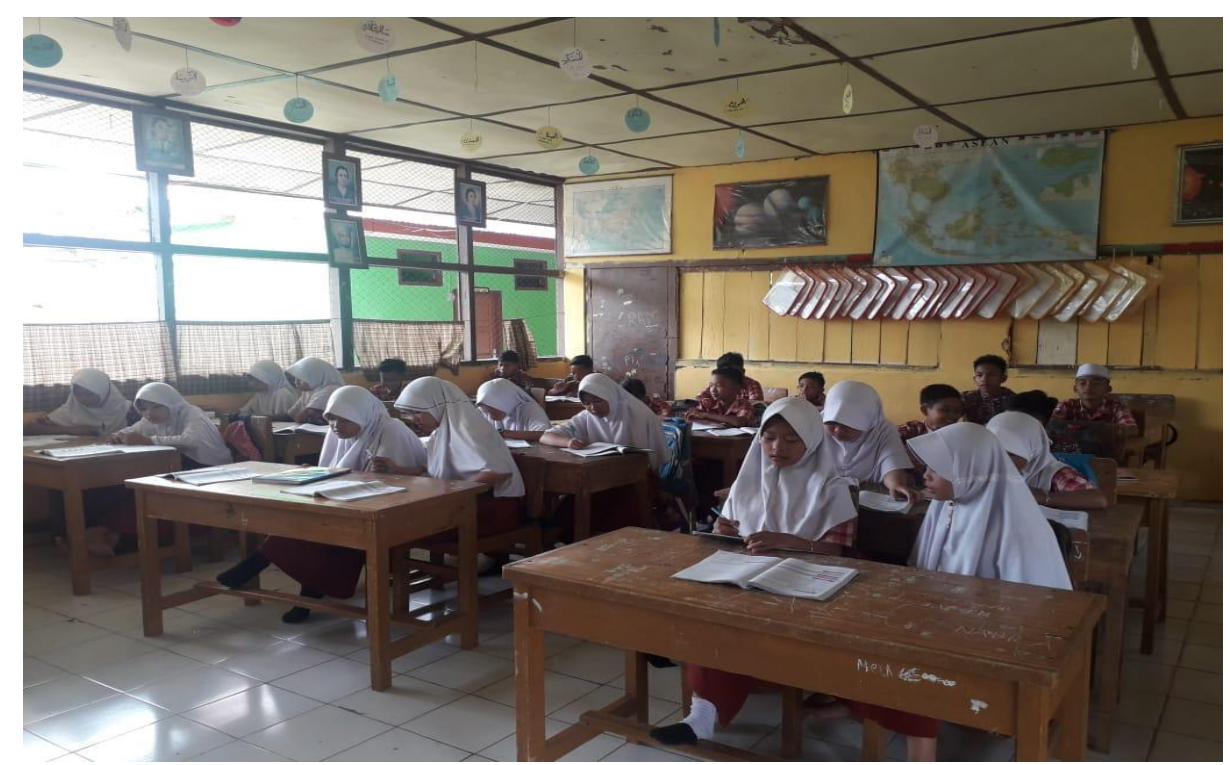

Gambar 2. Proses Pembelajaran yang di lakukan di dalam Kelas

Masyarakat Suku Anak Dalam atau Orang Rimba di Desa Pulau Lintang ini sudah sangat terbuka dengan pendidikan, hal tersebut dapat dilihat dari minat dan prestasi anak-anak Orang Rimba yang sudah sekolah di sekolah formal tersebut. Modal sosial menjadi bekal yang dimiliki Orang Rimba sehingga mampu berinteraksi dan bersaing dengan masyarakat di luar sukubangsanya. Dari hasil penelitian yang telah peneliti lakukan, peneliti dapat menjelaskan modal sosial yang dimiliki Orang Rimba untuk pendidikan formal anak-anak mereka khususnya untuk menyekolahkan anak-anak mereka di SDN 89/VII Desa Pulau Lintang sebagai berikut:

\section{Jaringan Sosial}

Jaringan sosial terbentuk karena adanya proses terlebih dahulu yang harus dilalui yaitu menjalin hubungan sosial. Adanya hubungan yang dijalin pemerintah dengan Orang Rimba dan hubungan yang dijalin antara guru nonformal dengan masyarakat Orang Rimba sehingga anakanak Orang Rimba di desa Pulau Lintang bisa mendapatkan pendidikan di sekolah formal.

\section{Orang Rimba dengan Pemerintah}

Salah satu jaringan sosial yang dimiliki Orang Rimba untuk menyekolahkan anak-anaknya di sekolah formal adalah pemerintah, pemerintah menginginkan masyarakat Orang Rimba juga mendapatkan pendidikan formal bersama dengan anak-anak desa. Pendidikan Orang Rimba ini menjadi program pemerintah untuk memberantas buta aksara pada kalangan Orang Rimba dan agar anak-anak Orang Rimba mendapatkan haknya di bidang pendidikan. Selain menginginkan anak-anak Orang Rimba bisa sekolah di sekolah formal, pemerintah juga memfasilitasi semua keperluan sekolah anak-anak Orang Rimba seperti semua perlengkapan sekolah anak-anak orang rimba dan memberikan uang senilai lima puluh ribu rupiah setiap bulannya untuk uang jajan anakanak orang rimba di sekolah.

\section{Guru Nonformal}

Orang Rimba mendapatkan bantuan untuk bisa mendaftar ke sekolah formal karena hubungan sosial yang dimiliki antara Orang Rimba dengan guru pendidikan nonformalnya. Guru non formal ini adalah pak Mad dan ibu Nova. Hubungan pemerintah, guru nonformal dengan Orang Rimba berperan sebagai keuntungan bersama karena pemerintah bisa mengurangi angka buta aksara pada Orang Rimba, guru nonformal bisa menjalankan tugasnya dengan baik dan Orang Rimba terbantu dengan adanya bantuan dari pemerintah dan guru nonformal tersebut. 
Guru tersebut yang membantu anak-anak Orang Rimba membaca, menulis dan berhitung sehingga anak-anak Orang Rimba bisa dengan cepat memahami pelajaran yang mereka dapatkan di sekolahnya dan guru nonformal yang membuat Orang Rimba merasa terbantu dengan pendataan keperluan sekolah anak-anak Orang Rimba untuk diberikan kepada pemerintah, hal tersebut dapat membantu Orang Rimba yang tidak mengerti dalam urusan mendaftarkan anaknya ke sekolah dan membantu Orang Rimba yang sulit dalam keadaan ekonomi. Orang Rimba sangat percaya dengan guru sekolah nonformal tersebut, hal ini sangat terlihat saat peneliti melakukan penelitian di pemukiman Orang Rimba, saat peneliti baru sampai ke lokasi penelitian, guru yang bernama pak Mad ini langsung meminta seluruh masyarakat untuk berkumpul dan menjelaskan maksud dan tujuan peneliti datang ke lokasi mereka tersebut. Guru tersebut juga meminta masyarakat tidak merasa takut saat diminta wawancara dan mau membantu peneliti dengan menjawab pertanyaan yang peneliti berikan. Hal tersebut membuktikan antara Orang Rimba dan guru sekolah nonformal memiliki hubungan yang dekat dan guru nonformal tersebut sangat bersedia membantu siapapun yang memiliki keperluan dengan masyarakat Orang Rimba agar mereka juga lebih terbiasa berinteraksi dengan masyarakat di luar sukubangsanya.

\section{Kepercayaan}

\section{Kepercayaan antara Orang Rimba dengan Pemerintah}

Kepercayaan yang lahir antara Orang Rimba dengan pemerintah timbul dikarenakan pemerintah memberikan fasilitas dan kebutuhan pendidikan untuk anak-anaknya. Orang Rimba percaya kepada pemerintah karena pemerintah sudah menolong anak-anak mereka untuk mendapatkan pendidikan yang layak dan memberikan semua kebutuhan sekolah, karena mereka tidak memiliki biaya untuk membelikan anak-anaknya perlengkapan dan seluruh kebutuhan sekolah seperti buku, seragam sekolah, tas dan per;engkapan sekolah lainnya, bahkan memberikan uang senilai lima puluh ribu rupiah setiap bulannya untuk uang jajan anak-anak orang rimba di sekolah. Orang Rimba berharap anak-anaknya tidak bodoh seperti mereka dan bisa mendapatkan pekerjaan di luar kebiasaan mereka suatu saat nanti.

\section{Kepercayaan antara Orang Rimba dengan guru Nonformal}

Kepercayaan yang lahir antara Orang Rimba dengan guru sekolah nonformal yaitu ibuk Nova da pak Mad muncul karena mereka sudah lama kenal dan dekat dengan guru yang mengajar anak-anaknya tersebut sejak anak-anak mereka belum mendapatkan pendidikan di sekolah formal hingga sekarang. Guru sekolah nonformal tersebut juga menjadi satu-satunya guru di SDN 89 yang mengurus dan mengontrol perkembangan anak-anak mereka di sekolah.

\section{Kepercayaan antar Orang Rimba dengan Pendeta}

Orang Rimba sudah menganut agama Kristen Protestan sejak tahun 2011. Sebelum mereka mengetahui adanya program dari pemerintah untuk memfasilitasi anak-anaknya di sekolah formal, Orang Rimba sudah mengetahui pentingnya pendidikan bagi mereka.

Orang Rimba percaya dengan apa yang disampaikan oleh pendeta. Kepercayaan tersebut timbual karena pendeta merupakan pembimbing umatnya, karena masyarakat Orang Rimba sudah meyakini ajaran agamanya, jadi mereka juga percaya sama apa yang disampaikan oleh pendeta. Hal tersebut membuka pikiran Orang Rimba untuk menyekolahkan anak-anaknya karena pendeta sudah meyakinkan pentingnya pendidikan bagi kehidupan mereka.

\section{Nilai dan Norma}

Nilai yang dianut Orang Rimba di desa Pulau Lintang ini ialah:

\section{Nilai Saling Menghargai}

Nilai saling menghargai terlihat dalam sikap Orang Rimba yang mentaati peraturan yang di berikan pemerintah dan guru nonformal seperti rajin belajar, berpakaian dengan rapi ke sekolah dan menjaga semua fasilitas yang diberikan oleh pemerintah. 


\section{Nilai Saling Tolong Menolong}

Nilai saling tolong menolong disini terlihat dari sikap menghargai dan mentaati peraturan yang sudah dibuat oleh pemerintah sehingga hal tersebut dapat menolong program pemerintah dalam menmberantas angka buta aksa pada Orang Rimba dan pendidikan anka-anak merekapun tertolong dengan adanya fasilitas yang diberikan oleh pemerintah. Nilai saling tolong menolong juga dilakukan oleh antar sesama Orang Rimba dengan saling membantu temannya yang tidak mengerti dengan tugas yang diberikan oleh gurunya di sekolah.

\section{Nilai Kesopanan}

Nilai kesopanan terlihat dari sikap anak-anak Orang Rimba yang menyambut kedatangan guru nonformalnya saat datang ke lokasi pemukiman mereka, dan kebiasaan mencium tangan saat bertemu dengan gurunya dan orang yang baru berkunjung ke lokasi tempat tinggal mereka

Dari data yang dikumpulkan dapat disimpulkan berdasarkan analisis teori Putnam bahwa jenis modal sosial yang ada pada Orang Rimba adalah jenis modal sosial bonding dan bridging. Modal sosial bonding dapat dilihat dari hubungan Orang Rimba dengan guru nonformalnya. Hubungan kedekatan mereka sudah seperti keluarga sendiri karena ibu nova dan pak mad yang lebih sering mengurus semua keperluan sekolah anak-anak orang rimba dan ibu nova sendiri menjadi satu-satunya guru yang menjadi penanggung jawab anak-anak orang rimba yang sekolah di SDN 89/VII Desa Pulau Lintang ini.

Selanjutnya terdapat modal sosial bridging, dimana pemerintah sudah membuat anak-anak Orang Rimba mendapatkan kesempatan untuk sekolah di sekolah formal yang sama dengan anakanak desa di luar sukubangsanya dan mendapatkan fasilitas yang sama dengan anak-anak desa. Hal tersebut sangat membantu Orang Rimba dalam keberlangsungan hidupnya.

Modal sosial Orang Rimba sangat berpengaruh terhadap meningkatkan minat anak-anak Orang Rimba untuk belajar dengan rajin di sekolah formal. Harapan-harapan yang muncul dari orang tua setelah anak-anak mereka mendapatkan pendidikan di sekolah membuat orang tua selalu menyemangati anak-anaknya untuk selalu rajin belajar.

Anak-anak Orang Rimba di desa Pulau Lintang kecamatan Bathin VIII Kabupaten Sarolangun sudah mendapatkan pendidikan formal di SDN 89/VII Desa Pulau Lintang. Walupun pendidikan formal merupakan hal baru bagi masyarakat orang rimba, namun anak-anak Orang Rimba di Desa Pulau Lintang mampu berinteraksi dengan baik dengan masyarakat di luar sukubangsanya dan mampu bersaing dengan anak-anak di luar sukubangsanya tersebut. Anakanak Orang Rimba yang sekolah di desa ini menggunakan seragam sekolah lengkap seperti anakanak desa lainnya dan mereka mendapatkan fasilitas yang sama dari pemerintah. Berbeda dengan anak-anak Orang Rimba di Dusun Selapik Kecamatan Mestong, Kabupaten Muaro Jambi, walupun Orang Rimba di dusun ini sudah menetap di rumah permanen dan berdampingan dengan masyarakat desa seperti Orang Rimba di Desa Pulau Lintang, namun anak-anak Orang Rimba di dusun Selapik ini tidak belajar di sekolah formal sama sekali, mereka hanya mendapatkan pendidikan di sanggar belajar "meraih mimpi" yang diurus oleh karang taruna setempat, dan waktu belajar yang mereka ikuti hanya 3 kali dalam seminggu dengan fasilitas seadanya, penyebab utama anak-anak Orang Rimba di Desa Selapik ini tidak sekolah di pendidikan formal yaitu masalah biaya (Asra, Revis, 2018). Sangat berbeda dengan anak-anak Orang Rimba di Desa Pulau Lintang yang sudah mendapatkan pendidikan formal dan sudah sekolah di sekolah yang sama dengan anak-anak masyarakat di luar sukubangsanya. Di Desa Pulau Lintang pemerintah memberikan kesempatan kepada anak-anak Orang Rimba untuk sekolah di sekolah formal dan memfasilitasi keperluan sekolahnya agar mereka mendapatkan haknya dalam bidang pendidikan dan dapat mengurangi angka buta aksara pada kalangan Orang Rimba di Kabupaten Sarolangun.

Berdasarkan pandangan teori modal sosial Putnam, kepercayaan antara Orang Rimba dengan jaringan mereka terbentuk karena interaksi antara Orang rimba dengan pemerintah dan Orang Rimba dengan guru pendidikan nonformal. Sedangkan nilai dan norma terbentuk karena adanya kesepakatan dan kepercayaan antara Orang Rimba dengan pemerintah, Orang Rimba

Culture \& Society: Journal of Anthropological Research Vol. 1, No. 4, Th. 2020 
dengan guru pendidikan nonformal dan Orang Rimba dengan pendeta. Dengan adanya jaringan sosial dan kepercayaan membentuk nilai dan norma yang dianut masyarakat Orang Rimba. Jaringan sosial tersebut berperan dalam memperluas kerjasama dengan orang lain.

\section{Kesimpulan}

Berdasarkan hasil penelitian yang telah peneliti lakukan, maka dapat diketahui bahwa anakanak Orang Rimba di Desa Pulau Lintang yang sekolah di sekolah formal bersama anak-anak desa di luar sukubangsanya terjadi karena Orang Rimba memiliki modal sosial yang pertama, jaringan yang mereka dapatkan dari hubungan sosial dengan pemerintah; dan guru nonformal anak-anak Orang Rimba yang membantu anak-anak mendapatkan kesempatan sekolah di sekolah formal; dan membantu anak-anak Orang Rimba untuk mendapatkan fasilitas tersebut. Kedua kepercayaan yang dimiliki Orang Rimba dengan pemerintah, guru nonformal dan pendeta yang membuat anak-anak mereka semangat dalam menjalankan kewajibannya. Ketiga nilai kesopanan, saling menghargai dan saling tolong menolong yang mereka anut.

\section{Daftar Pustaka}

Asra, A., et al. (2018). Peningkatan Kualitas Pendidikan untuk Anak Suku Anak Dalam di Dusun Selapik, Kabupaten Muaro Jambi. Karya Abdi Masyarakat, 2(1), 2-8. https://doi.org/https://doi.org/10.22437/jkam.v2i1.5424

Bachri, B. S. (2010). Meyakinkan Validitas Data Melalui Triangulasi Pada Penelitian Kualitatif. Teknologi Pendidikan, 10, 46-62.

Burhan, B. (2011). Penelitian Kualitatif. Jakarta: Kencana Perdana Media Group.

Fadilatur, R., Junaidi, J. \& Fernandes, R. (2019). Human Capitas Mahasiswa Universitas Terbuka Sebagai Guru Honorer (Studi Kasus: Guru Honorer di SD Negeri 1 Pangkalan, SD Negeri 10 Pangkalan, dan MIS Pangkalan, Kecamatan Pangkalan Koto Baru, Kabupaten Lima Puluh Kota). Jurnal Perspektif, 2(2), 66-74. http://dx.doi.org/ 10.24036/perspektif/v2i2.68

Febriani, D., Darusman, D., Ridho Nurrochmat, D., \& Wijayanto, N. (2012). Strategi Implementasi Kebijakan Hutan Tanaman Rakyat Di Kabupaten Sarolangun, Jambi. Jurnal Analisis Kebijakan Kehutanan, 9(2), 81-95. https://doi.org/10.20886/jakk.2012.9.2.81-95

Hidayat, H., Syamsulm, M., Rahardjo, T., Suprihatini, T. (2013). Penerimaan Suku Anak dalam Terhadap Pendidikan. Interaksi Online, 1(4), 26-33.

Inayah, I. (2012). Peran Modal Sosial dalam Pembangunan. Jurnal Penngembangan Humaniora, 12, 43-47.

Juanda, J. (2010). Peranan Pendidikan Formal dalam Proses Pembudayaan. Lentera Pendidikan: Jurnal Ilmu Tarbiyah dan Keguruan, 13(1), 1-15. https://doi.org/10.24252/1p.2010v13n1a1

Kamarni, N. (2012). Analisis Modal Sosial Sebagai Salah Satu Upaya dalam Pengentasan Kemiskinan. Studi Kasus: Rumah Tangga Miskin di Kecamatan Koto Tangah Kota Padang. Manajemen dan Kewirausahaan, 3(3), 36-52.

Lestari, Rian Aji ; Anwar, S. M. (2015). Pendidikan Antisipatoris Dalam Menghadapi Arus Transformasi Dunia Pada Novel Sokola Rimba Karya Butet Manurung. Buana Bastra, 2(2), $115-131$.

Mulyadi, M. (2013). Penelitian Kuantitatif Dan Kualitatif Serta Pemikiran Dasar Menggabungkannya. Jurnal Studi Komunikasi dan Media, 15(1), 128. https://doi.org/10.31445/jskm.2011.150106

Nawawi, H. (2012). Metode Penelitian Bidang Sosial. Yogyakata: Gajah Mada University Press.

Ristami, E. (2016). Peran Modal Sosial dalam Memperkuat Strategi Bertahan Hidup Penambang Batu (Kelurahan Sepancar Lawang Kulon, Kecamatan Baturaja Timur, Sumatera Selatan). 
Shabrina, G. N. (2015). Peranan Modal Sosial Dalam Meningkatkan Efektivitas Program Corporate Social Responsibility Dan Taraf Hidup Masyarakat Gina Nefstia Shabrina. Skripsi. Institut Pertanian Bogor.

Sudjana, D. (2004). Pendidikan Nonformal (Wawasan, Sejarah Perkembangan, Filsafat, Teori Pendukung, Asas). Bandung: Falah Production. 